\title{
UDO SCHWERTMANN (25 November 1927-20 January 2016)
}

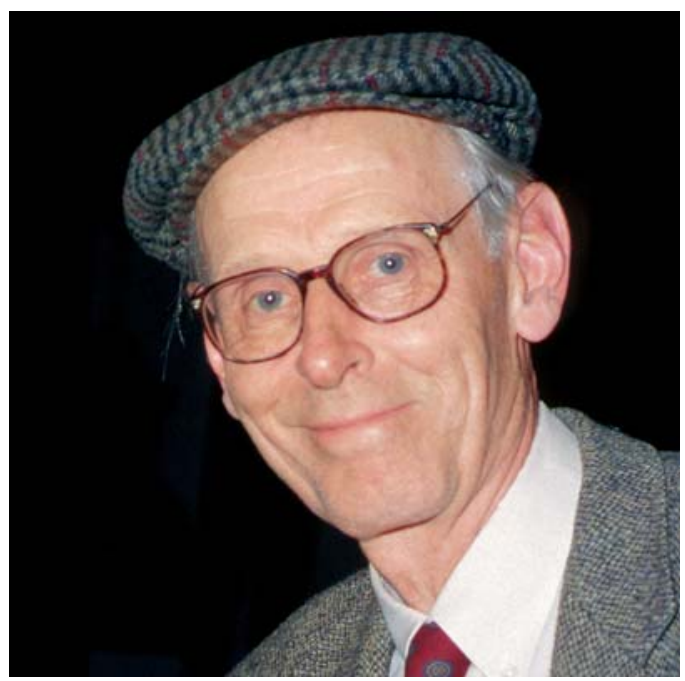

It is with infinite sadness that I write these lines.

I first met Udo Schwertmann in the spring of 1975. His department was seeking a scientist with experience in X-ray methods (XRD and XRF) and I was looking for a job. To me, a young upstart with a $\mathrm{PhD}$ and experience in igneous petrology and geochemistry, soils were something like 'yukk'. In the end, Schwertmann taught me to respect soils and practically all that I know about soils and clays.

First, the sheer size of this 2-metre tall, wiry man was impressive. Then there was the reserved dignity of the North-German Hanseatic gentleman: style without a trace of aloofness.

So much for my personal reminiscences.

Schwertmann was a critical person. Seldom enough among university professors, he was also willing to accept criticism from anyone as long as it was founded. Nothing would annoy him more than unsubstantiated statements, and he was willing to criticize and, if necessary even antagonize, colleagues (including fellow professors) who were careless enough to utter such statements.

Schwertmann had an excellent command of the English language, an important prerequisite for editorship of a journal, and so it comes as no surprise that Schwertmann was Associate Editor of Clay Minerals for 16 years, on the Editorial Board of which he served since its 'Europeanization' in 1976 until his demise. He was also Associate Editor of the journal Clays and Clay Minerals from 1980 to 1992 (D.C. Bain \& J.W. Stucki, pers. comm.).

As a researcher, Schwertmann is best known for his work on the iron oxides. This work led to the publication of a multitude of articles and review papers, and culminated in the publication of two books (both currently in the second edition) together with Rochelle ('Shelley') Cornell, on the synthesis of oxides that occur in nature (Schwertmann \& Cornell, 1991) and a colossal oeuvre on the properties, reactions, occurrences and uses of iron oxides (Cornell \& Schwertmann, 2003) that some colleagues behind his back referred to informally as the "iron oxide bible'. Together with Joe Stucki and Bernard Goodman, he also co-edited a book on iron in soils and clay minerals (Stucki et al., 1988).

Schwertmann was active in soil-related topics other than the iron oxides: soil fertility and soil erosion, and the ensuing loss of valuable top soil were major concerns of his, and he also published numerous journal articles on these subjects. Together with his students and research associates Karl Auerswald, Willi Vogl and Max Kainz he wrote books on soil erosion (e.g. Schwertmann et al., 1989, 1990), and, among other key works, he contributed substantially to several 
editions of the 'classic' German-language textbook on soil science, the 'Scheffer/Schachtschabel' (Schachtschabel et al., 1976-1998).

Schwertmann travelled often, mostly to institutions in which work similar to his own was being carried out. Conversely, scientists from all over the world flocked to his department to work on subjects related to soils sensu lato. One of the guests he hosted, Jerry Bigham, a professor of soil science from Ohio, brought along numerous samples of acid-mine precipitates, some of which contained a hitherto unknown phase, which the International Mineralogical Association (IMA) eventually officially approved as a 'new' mineral named schwertmannite, ideally $\mathrm{Fe}_{8} \mathrm{O}_{8}(\mathrm{OH})_{6} \mathrm{SO}_{4}$, in honour of Udo Schwertmann (Bigham et al., 1994).

ENVER MURAD

\section{REFERENCES}

Bigham J.M., Carlson L. \& Murad E. (1994) Schwertmannite, a new iron oxyhydroxysulphate from Pyhäsalmi, Finland, and other localities. Mineralogical Magazine, 58, 641-648.
Cornell R.M. \& Schwertmann U. (2003) The Iron Oxides - Structure, Properties, Reactions, Occurrences and Uses, 2nd edition. Wiley-VCH, Weinheim, Germany, $664+$ xxxvii pp.

Schachtschabel P., Blume H.-P., Brümmer G., Hartge K. H. \& Schwertmann U. (1976-1998) Scheffer/ Schachtschabel: Lehrbuch der Bodenkunde, 9th14th edition. Ferdinand Enke Verlag, Stuttgart, Germany (14th edition: $494+$ xii pp).

Schwertmann U. \& Cornell R.M. (1991) Iron Oxides in the Laboratory - Preparation and Characterization, 2nd edition. Wiley-VCH, Weinheim, Germany, $188+$ xviii pp.

Schwertmann U., Rickson R.J. \& Auerswald K. (1989) Soil Erosion Protection Measures in Europe. Soil Technology Series 1, Catena Verlag, Reiskirchen, Germany, 216 + viii pp.

Schwertmann U., Vogl W. \& Kainz M. (1990) Bodenerosion durch Wasser: Vorhersage des Abtrags und Bewertung von Gegenmaßnahmen, 2nd edition. Eugen Ulmer Verlag, Stuttgart, Germany, 64 pp.

Stucki J.W., Goodman B.A. \& Schwertmann U., editors (1988) Iron in Soils and Clay Minerals. Springer, Dordrecht, Netherlands, $893+$ xviii pp. 